\title{
EVALUATION OF LUNG INFILTRATION SCORE TO PREDICT \\ POSTURAL HYPOXEMIA IN VENTILATED ACUTE RESPIRATORY DISTRESS SYNDROME PATIENTS AND THE LATERALIZATION OF SKIN PRESSURE SORE
}

MUKESH TRIPATHI, MAMTA PANDEY, BHARAT NEPAL, HARI RAI, BALKRISHNA BHATTARAI

\section{ABSTRACT}

CONTEXT: Mechanical ventilation with positive end expiratory pressure (PEEP) is associated with unequal aeration of lungs in acute respiratory distress syndrome (ARDS) patients. Therefore, patients may develop asymmetric atelectasis and postural hypoxemia during lateral positioning. AIMS: To validate proposed lung infiltration score (LIS) based on chest x-ray to predict postural hypoxemia and lateralization of skin sores in ARDS patients. SETTINGS AND DESIGN: University hospital ICU. Prospective, observational study of consecutive patients. MATERIALS AND METHODS: Sixteen adult patients of both genders on mechanical ventilation with PEEP for 24 to $<48$ hours. On chest x-ray, 6 segments were identified on each lung. The proposed LIS points (0-normal; 1- patchy infiltrates; 2- white infiltrates matching heart shadow) were assigned to each segment. Without changing ventilation parameters, supine, left and right lateral positions at $45^{\circ}$ tilt were randomly changed. At the end of $\mathbf{2 0}$ minutes of ventilation in each position, we observed arterial oxygen saturation, hemodynamic and arterial blood gases. Later, position change protocol (4 hourly) was practiced in ICU, and skin pressure sore grading was noted within a week of ICU stay. STATISTICAL ANALYSIS USED: Nonparametric Bland and Altman correlation analysis, ANOVA and Student t test. RESULTS: Arterial oxygenation $\left(\mathrm{PaO}_{2} / \mathrm{FiO}_{2}=313 \pm 145.6\right)$ was significantly $(\mathrm{P}<0.01)$ higher in better lung (lower LIS)-down position than supine $\left(\mathrm{PaO}_{2} / \mathrm{FiO}_{2}=199 \pm 70.2\right)$ or a better lung-up position $\left(\mathrm{PaO}_{2} / \mathrm{FiO}_{2}=165 \pm 64.8\right)$. The positioning-related arterial oxygenation was significant $(P<0.05)$ at LIS asymmetry $\geq 3$ between two lungs. CONCLUSIONS: The LIS mapping on chest $x$-ray was useful to differentiate between asymmetric lung disease and postural hypoxemia in ICU patients, which predisposed patients to early skin sore changes on higher LIS side.

Key words: Ayurvedic medication, d-Penicillamine, lead poisoning, peripheral neuropathy

DOI: $10.4103 / 0019-5359.56110$

Department of Anaesthesiology and Critical Care,

BPKIHS, Dharan, Nepal

Correspondence:

Prof. Mukesh Tripathi

C- 7.1.1, BPKIHS Campus, Dharan, Nepal

E-mail: mukesh_tripathi@ hotmail.com

\section{INTRODUCTION}

The cyclic positioning in mechanically ventilated patients is practiced to prevent pressure sores, improve oxygenation, mobilize secretions and 
decrease the incidence of ventilator-associated pneumonia. ${ }^{[1-3]}$ Hypoxemia (decreased arterial blood oxygen level) is reported during lateral positioning of patients with unilateral lung disease. ${ }^{[4-7]}$ Acute respiratory distress syndrome (ARDS) is the most common pathology of respiratory failure in intensive care unit (ICU) requiring mechanical ventilation. The syndrome is characterized by refractory hypoxemia with bilateral diffuse infiltrates in lungs on chest $\mathrm{x}$-ray. ${ }^{[8]}$ Although radiographically and by definition, ARDS is a bilateral lung disease, blood oxygenation $\left(\mathrm{PaO}_{2}\right)$ in 5 of the 6 studied patients differed during lateral positioning, suggesting asymmetric lung involvement. ${ }^{[9]}$ Since variable effects on oxygenation during lateral positioning of patients have been reported, ${ }^{[4,10-13]}$ the effects of lateral positioning of ARDS patients are unclear. After extensive literature search, we did not find a method to quantify or predict the asymmetry of the lung disease. Therefore, we proposed a lung infiltration score (LIS) for the chest $x$-ray and evaluated it in predicting the risk of postural hypoxemia in ARDS patients.

The problem of skin pressure sore has been widely discussed in the care of chronic patients but has become a point of concern in ICU, due to its far-reaching impact on cost of therapy and duration of hospital stay. ${ }^{[14,15]}$ Factors like older age, activity, immobilization, diminished pain sensation, moist skin, poor nutrition, friction and shear have been reported to predispose $68.4 \%$ of ICU patients for skin pressure sores (grade-2) within a week of ICU stay. ${ }^{[16]}$ Thus a secondary area of the study was to look for lateralization of skin pressure sores, as tissue hypoxia might predispose towards bed sore formation.

\section{MATERIALS AND METHODS}

We took approval from the institute's ethical committee and obtained informed written consent from the kin of every patient after explaining the nature of study. Patients who satisfied the following inclusion criteria for diagnosis of ARDS were admitted to the study: respiratory rate $\geq 30 / \mathrm{min}$, chest $x$-ray with bilateral infiltrates, $\mathrm{PaO}_{2} / \mathrm{FiO}_{2}<150,{ }^{[9]}$ $\mathrm{PaO}_{2} / \mathrm{FiO}_{2}<200$ with PEEP ${ }^{[17]}$ and hypocarbia $\left(\mathrm{PaCO}_{2}<32 \mathrm{~mm} \mathrm{Hg}\right)$.

Since $\mathrm{PaO}_{2} / \mathrm{FiO}_{2}$ ratio of $<200$ is one of the ARDS criteria, for sample size calculation a $50 \%$ change in it was taken as a clinically significant difference. Assuming a standard deviation of $50, \alpha$-error of 0.05 and power $(1-\beta)$ of $95 \%, 15$ patients were desired to be studied on applying priori $t$ test for two independent means. Thus prospective clinical study was performed on consecutive 16 adult (18-68 years of age) patients of both genders (8 male, 8 female) admitted to ICU in a 2-month period. They presented with ARDS of varied etiologies (abdominal sepsis- patient nos.1-3, 12-16; aspiration infiltrates- 6, 10; pneumonitis- 4, 5, 7; scorpion sting- $8,9,11$ ). Patients were on mechanical ventilation with PEEP $(5-12 \mathrm{~cm}$ $\mathrm{H}_{2} \mathrm{O}$ ) for $\geq 24$ hours to $<48$ hours and had improvement in oxygenation $\left(\mathrm{PaO}_{2} / \mathrm{FiO}_{2} \geq 200\right)$. Patients having hemodynamic instability and/ or on inotropes were excluded.

Bedside chest $x$-ray (AP view) was taken on the day of study in expiratory phase after detaching ventilator. It was graded as follows: each lung field in the chest $x$-ray was divided into 3 zones on the basis of anterior shadow of ribs: upper zone- above the $2^{\text {nd }}$ rib; middle 
zone- from $2^{\text {nd }}$ to $4^{\text {th }}$ ribs; lower zone- from $4^{\text {th }}$ rib to dome of diaphragm. All 3 zones were further divided into medial and lateral halves, by the imaginary vertical line in between the midline (vertebral spines) and the tangential vertical line along the outer margin of the rib cage on both hemithoraces. Thus each lung was divided into 6 segments [Figure 1]. On the basis of the radiolucency of the lung infiltrates in the chest $\mathrm{x}$-ray, LIS points were assigned to each segment. LIS points scaled from 0 to 2 as follows: 0- normal alveolar picture; 1- patchy white infiltrates; 2 - totally white infiltrates (radiolucency matching the heart shadow) [Figure 1]. Only in the left medial lower zone, the scoring criteria were modified as LIS 0 - normal heart shadow; 1- when bronchial web on heart shadow; and 2- radiolucency of infiltrate more than adjacent heart shadow with blurring of the heart border. Thus the maximum LIS that could be given was 12 for each lung and 24 for each patient. The LIS grading was done by the nursing staff ( 6 nurses scored 2 chest $x$-rays and 1 nurse scored 4 x-rays) attending to the patients. For validation, the same radiologist independently gave LIS points to all chest $\mathrm{x}$-rays [Figure 1].

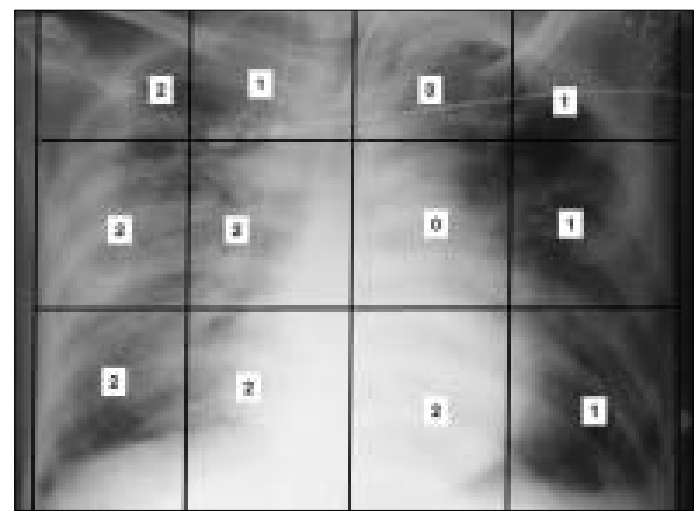

Figure 1: Details of lung infiltration score (LIS) assigned to different lung segments on chest $\mathrm{x}$-ray of patient no.10
Patients were monitored for changes in ECG lead II, arterial blood pressure, central venous pressure (CVP), arterial oxygen saturation by pulse oximetry $\left(\mathrm{SpO}_{2}\right)$, inhaled oxygen level $\left(\mathrm{FiO}_{2}\right)$, and arterial blood gas (ABG) parameters $\left(\mathrm{pH}, \mathrm{PaO}_{2}, \mathrm{PaCO}_{2}, \mathrm{HCO}_{3}\right.$, base deficit) during supine, left lateral by $45^{\circ}$ tilt and right lateral by $45^{\circ}$ tilt positions. The 3 positions were sequenced in random fashion by using sealedenvelope technique. The observer was kept blinded for the LISs of the chest $x$-rays. All the observations were noted after 20 minutes in each position. All patients were sedated and muscle relaxant was given to maintain identical ventilation settings during the study period. As a rescue measure, only $\mathrm{FiO}_{2}$ was increased at any point of study in case $\mathrm{SpO}_{2}$ dropped to a level $<90 \%$.

Data were sorted into 3 groups: group 1 ( $n=$ 16)- lateral position with better lung (lower LIS) down; group 2 ( $n=16)$ - supine position and group 3 ( $n=16)$ - lateral position with better lung up. We compared hemodynamic parameters, $A B G$ and the calculated values of $\mathrm{PaO}_{2} /$ $\mathrm{FiO}_{2}$, alveolar-arterial $\mathrm{O}_{2}$ pressure difference $\left(\mathrm{AaDpO}_{2}\right)\left[(\mathrm{PB}-47) \times \mathrm{FiO}_{2}-\left(\mathrm{paCO}_{2} / 0.8\right)-\mathrm{PaO}_{2}\right]$ in these 3 groups.

Lung infiltrates asymmetry (right LIS-left LIS) was also calculated for each patient. Its positive value indicated that the right lung was more diseased than the left lung, and the negative value indicated that the left lung was more diseased than the right lung. We regrouped patients on the basis of LIS differences between the two lungs, i.e., LIS $\leq$ $2(n=6)$; for 3 or $4(n=7)$; and $\geq 5(n=3)$ and compared oxygenation parameters to find out the significant lung infiltrates asymmetry related 
with the postural hypoxemia.

The skin pressure sores were graded on 1 to 4 scale: stage 1- surface reddening of the skin like a bruise with intact skin; stage 2- blister, either broken or unbroken; stage 3- all the skin layers involved in wound; stage 4- wound involves the muscle, tendons and bones. ${ }^{[16]}$ As per our ICU protocol, the cyclic change (4 hourly) of patient position from supine to right or left lateral was carried out in the subsequent days. The site and worst grades of pressure sores (sacrum, iliac crest and greater trochanter on both sides) were noted from the bedsore nursing chart in ICU in the next 1 week of the study period.

\section{Statistics}

All data were entered in statistical package SPSS-10.0 for windows (SPSS Inc., Chicago, $\mathrm{IL})$. One-way analysis of variance (ANOVA) for descriptive data, nonparametric two-tailed Pearson's correlations coefficient, regression analysis of lung infiltrates asymmetry, Spearman's Rho and $x^{2}$ test were used. Calculated value of $P<.05$ at $95 \%$ confidence interval was considered statistically significant.
The agreement between data pairs for the total LIS for each lung on chest $x$-ray given by the radiologist and nursing staff was analyzed by Bland and Altman analysis. Upper and lower limits of agreement, calculated as mean bias $\pm 1.96 \mathrm{SD}$ of the difference between the LISs, were scored for each chest $\mathrm{x}$-ray.

\section{RESULTS}

The studied patients were 18 to 68 years of age, weighed 40 to $85 \mathrm{~kg}$ and had an APACHIII score of 14 to 28 with a total LIS of 5 to 18 . Patient no. 7 had bilaterally equal LIS with a total of 16 , i.e., 8 for each side. Right LIS $\geq$ left LIS was found in 6 patients; and left LIS $\geq$ right LIS, in 9 patients. The difference in LIS for the two lungs ranged from -5 (left lung LIS $\geq$ right lung LIS) to +6 (right lung LIS $\geq$ left lung LIS) [Table 1].

The scores given to bedside chest $x$-ray by the nursing staff and also independently assessed by a single radiologist showed a highly significant $(P<0.001)$ correlation $(\mathrm{R}=0.86)$ for the total LIS of the two lungs. A Bland-Altman analysis of total LIS for the right and left lungs

Table 1: Patient characteristics, chest $\mathrm{x}$-ray score by radiologist

\begin{tabular}{|c|c|c|c|c|c|c|c|c|c|}
\hline $\begin{array}{l}\text { Age } \\
\text { (yrs) }\end{array}$ & Sex & $\begin{array}{c}B M I \\
\left(\mathrm{~kg} / \mathrm{m}^{2}\right)\end{array}$ & $\begin{array}{c}\text { APACHI-II } \\
\text { Score }\end{array}$ & $\begin{array}{c}\text { Right } \\
\text { Lung LIS }\end{array}$ & $\begin{array}{c}\text { Left } \\
\text { Lung LIS }\end{array}$ & Total LIS & $R t$ LIS-Lt LIS & $\begin{array}{c}\text { PEEPI } \\
\left(\mathrm{cm} \mathrm{H} \mathrm{H}_{2} \mathrm{O}\right)\end{array}$ & $\begin{array}{l}\text { Minute volume } \\
\text { (L/min) }\end{array}$ \\
\hline 40 & Male & 27 & 28 & 3 & 7 & 10 & -4 & 10 & 11 \\
\hline 35 & Female & 26 & 32 & 6 & 9 & 15 & -3 & 12 & 10 \\
\hline 20 & Male & 23 & 13 & 7 & 11 & 18 & -4 & 15 & 9 \\
\hline 68 & Female & 25 & 14 & 8 & 6 & 14 & 2 & 12 & 8.5 \\
\hline 40 & Male & 27 & 18 & 2 & 7 & 9 & -5 & 08 & 7.8 \\
\hline 48 & Male & 23 & 18 & 7 & 1 & 8 & 6 & 08 & 6 \\
\hline 18 & Female & 18 & 23 & 8 & 8 & 16 & 0 & 15 & 5.2 \\
\hline 48 & Male & 23 & 18 & 2 & 3 & 5 & -1 & 05 & 6 \\
\hline 43 & Female & 30 & 21 & 6 & 4 & 10 & 2 & 10 & 8 \\
\hline 20 & Female & 26 & 20 & 11 & 5 & 16 & 6 & 15 & 8 \\
\hline 54 & Male & 24 & 26 & 7 & 5 & 12 & 2 & 10 & 7.2 \\
\hline 30 & Female & 18 & 18 & 4 & 8 & 12 & -4 & 10 & 4.6 \\
\hline 52 & Male & 20 & 19 & 4 & 7 & 11 & -3 & 12 & 5.6 \\
\hline 52 & Female & 27 & 24 & 5 & 9 & 14 & -4 & 15 & 6.5 \\
\hline 62 & Male & 30 & 26 & 7 & 3 & 10 & 4 & 10 & 7.5 \\
\hline 29 & Female & 23 & 28 & 4 & 6 & 10 & -2 & 12 & 5 \\
\hline
\end{tabular}

APACHI-II: acute physiological and chronic health index-II; LIS: lung infiltration score; BMI: body-mass index; Rt: right; Lt: left. 
by radiologist and the nursing staff revealed a mean bias of -0.16 . Limits of agreement were -2.93 and 2.61 to include $95 \%$ points within the range of LIS point differences between the radiologist and nursing staff [Figure 2].

During the 3 position changes in the studied patients, $\mathrm{PaO}_{2} / \mathrm{FiO}_{2}$ significantly $(P<0.01)$ improved in patients lying on their better lung than supine or lying on their bad lung. $\mathrm{SpO}_{2}$ did not change significantly but for 2 patients, who developed desaturation lying on their bad lung, and the $\mathrm{FiO}_{2}$ was increased [Figures 3 and 4].

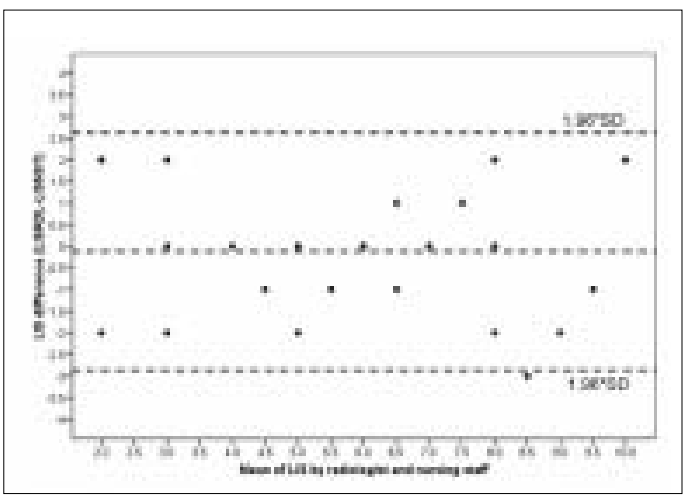

Figure 2: Bland-Altman analysis - correlation of LISRDL and LISNST on same chest $x$-ray (LISRDL: lung infiltration score by same radiologist; LISNST: lung infiltration score by nursing staff)
Regrouping of the data on the basis of better lung-up or -down position, the oxygenation parameters $\left(\mathrm{PaO}_{2}, 169 \pm 77.6 \mathrm{~mm} \mathrm{Hg} ; \mathrm{PaO}_{2} /\right.$ $\left.\mathrm{FiO}_{2}, 313 \pm 145.6\right)$ in group 1 (better lung down) were significantly $(P<0.001)$ higher than those in group 2 (supine) or group 3 (better lung up) positions. The parameters $\left(\mathrm{SpO}_{2}, \mathrm{PaO}_{2}, \mathrm{PaO}_{2} /\right.$ $\mathrm{FiO}_{2}$ and $\mathrm{AaDpO}_{2}$ ) in supine position were found to be in between the two lateral positions. Other clinical parameters like heart rate, mean arterial pressure, CVP, $\mathrm{PaCO}_{2}$ did not change significantly [Table 2].

The arterial blood oxygenation parameters $\left(\mathrm{PaO}_{2}, \mathrm{PaO}_{2} / \mathrm{FiO}_{2}\right.$ and $\left.\mathrm{AaDpO}_{2}\right)$ significantly $(P<0.05)$ changed during the 3 positions in patients with LIS difference $\geq 3$. At LIS difference $\geq 4, \mathrm{PaO}_{2} / \mathrm{FiO}_{2}(501 \pm 123)$ was the highest and $\mathrm{AaDpO}_{2}(83 \pm 88.3)$ was the lowest in better lung-down position. In patients with lesser difference between the two lungs (LIS $\leq 2)$, the 3 parameters did not change significantly [Table 3].

Out of the 16 studied patients, majority $(9,56 \%)$ of the patients had left lung worse than the right. Skin pressure sore grade 2 (skin redness, blisters) was more commonly $(7,44 \%)$ seen

Table 2: Observed parameter changes. (mean+SD)

\begin{tabular}{|c|c|c|c|c|}
\hline & Group $1(n=16)$ & Group $2(n=16)$ & Group $3(n=16)$ & $\begin{array}{c}P \text { value } \\
\text { Significance }\end{array}$ \\
\hline Characteristic & $\begin{array}{l}\text { Better lung (lower LIS) } \\
\text { Down position }\end{array}$ & Supine position & $\begin{array}{c}\text { Better lung (lower LIS) } \\
\text { up position }\end{array}$ & \\
\hline Heart Rate (bpm) & $111+18.9$ & $109+15.9$ & $115+16.3$ & $0.55 \mathrm{NS}$ \\
\hline Mean Arterial Pressure $(\mathrm{mmHg})$ & $92+12.9$ & $95+8.8$ & $96+12.1$ & $0.58 \mathrm{NS}$ \\
\hline Central venous pressure $(\mathrm{cmH} 2 \mathrm{O})$ & $6.4+2.8$ & $6.3+2.8$ & $6.6+3.2$ & $0.97 \mathrm{NS}$ \\
\hline $\mathrm{SpO} 2(\%)$ & $98+1.9$ & $97+2.2$ & $95+3.7^{\dagger}$ & $0.03 \mathrm{~S}$ \\
\hline $\mathrm{PaO} 2(\mathrm{mmHg})$ & $169+77.6^{*}$ & $115+46.5$ & $89+33.9^{\dagger}$ & $0.001 \mathrm{HS}$ \\
\hline $\mathrm{PaO} 2 / \mathrm{FiO} 2$ ratio & $313+145.6^{*}$ & $199+70.2$ & $165+64.8^{\dagger}$ & $0.001 \mathrm{HS}$ \\
\hline $\mathrm{PaCO} 2(\mathrm{mmHg})$ & $37.5+9.1$ & $39.5+10.2$ & $39.1+10.0$ & $0.87 \mathrm{NS}$ \\
\hline $\mathrm{AaDpO} 2$ & $199+24.5$ & $249+20.1$ & $276+21.7^{\dagger}$ & $0.04 \mathrm{~S}$ \\
\hline $\mathrm{pH}$ & $7.44+0.12$ & $7.40+0.08$ & $7.42+0.09$ & $0.50 \mathrm{NS}$ \\
\hline Bicarbonate (m.mol/l) & $25+6.5$ & $25+6.7$ & $26+6.9$ & $0.89 \mathrm{NS}$ \\
\hline
\end{tabular}

“*' - Significant $(P<0.05)$ difference from group 2 and 3 values based on Post-Hoc analysis, ${ }^{\dagger}$ - Significant $(P<0.05)$ difference from group 1 but not group 2 after Post-Hoc analysis 
on left greater trochanter compared to the right side $(3,19 \%)$. Hence the incidence of left-sided skin pressure sore was also more, especially the higher skin pressure sore grades, viz., 3 or 4. The worst skin pressure sore (grade 4) developed on sacrum in midline in $3(20 \%)$ patients; and in 1 (6\%), on the left greater trochanter [Table 4].

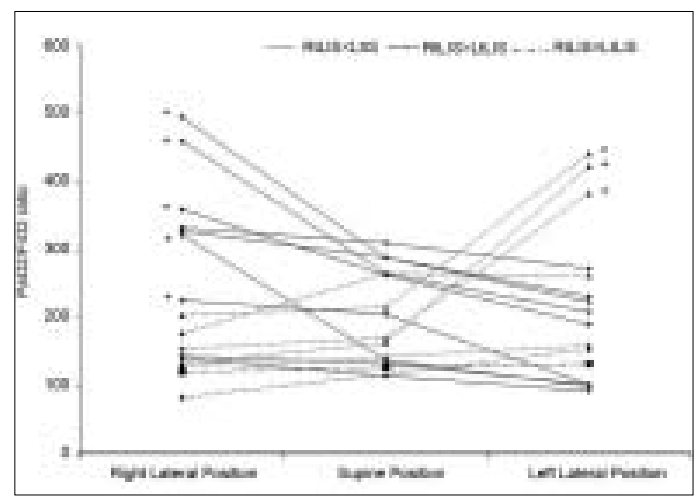

Figure 3: $\mathrm{PaO}_{2} / \mathrm{FiO}_{2}$ changes showed marked improvement in better lung-down lateral position when compared to supine position. '*' Statistically significant $(P<0.01)$ changes marked in patients with LIS asymmetry. The patient with smaller difference in LIS did not show significant change in the 3 positions

\section{DISCUSSION}

We observed that ARDS patients developed asymmetric lung infiltration after 24 hours of mechanical ventilation with PEEP (5-15 mm $\mathrm{Hg}$ ). The proposed simple LISs of bedside chest $x$-rays determined by the attending nurses significantly correlated with those determined by the radiologists. Patients with asymmetric lung score $(\geq 3)$ developed significant hypoxemia lying on the worse lung (higher LIS score) than when lying in the supine position or when lying on the better lung with an associated lateralization of the skin sores on the bony pressure points of the same side.

Arterial blood-gas composition is determined by alveolar ventilation, pulmonary blood flow and on the basis of how ventilation is matched to blood flow in the lungs. ${ }^{[18]}$ The lateral positioning with better lung down has long been recognized to give better arterial blood oxygenation than the better lung-up or the supine position in unilateral lung disease. ${ }^{[19]}$ In ventilated, sedated and paralyzed patients, the alveolar ventilation of dependent worse lung remains

Table 3: Relation of various parameters showing significant changes for difference on grouping in-between the two lungs scores difference for posture changes. (mean+SD)

\begin{tabular}{|c|c|c|c|c|}
\hline & $R t-L t$ difference (0-2) & Rt-Lt difference (3-4) & $R t-L t$ difference (>4) & $P$ value \\
\hline No of Patients & 6 & 7 & 3 & \\
\hline Group $1 \mathrm{PaO}_{2}(\mathrm{mmHg})$ & $135+60.4$ & $187+86.8^{*}$ & $193+89.2^{*}$ & $0.02 \mathrm{~S}$ \\
\hline Group $2 \mathrm{PaO}_{2}(\mathrm{mmHg})$ & $106+45.2$ & $127+44.6$ & $101+61.6$ & $0.65 \mathrm{NS}$ \\
\hline Group $3 \mathrm{PaO}_{2}(\mathrm{mmHg})$ & $86+33.5$ & $93+35.3^{\dagger}$ & $87+44.7^{\dagger}$ & $0.93 \mathrm{NS}$ \\
\hline$P$ value between position groups & $0.21 \mathrm{NS}$ & $0.027 \mathrm{~S}$ & $0.03 \mathrm{~S}$ & -- \\
\hline Group $1 \mathrm{PaO}_{2} / \mathrm{FiO}_{2}$ & $226+89.5$ & $308+126.2^{*}$ & $501+123.3^{*}$ & $0.015 \mathrm{~S}$ \\
\hline Group $2 \mathrm{PaO}_{2} / \mathrm{FiO}_{2}^{2}$ & $183+82.6$ & $204+69.4$ & $224+59.5$ & $0.72 \mathrm{NS}$ \\
\hline Group $3 \mathrm{PaO}_{2} / \mathrm{FiO}_{2}$ & $147+68.9$ & $154+52.4^{\dagger}$ & $225+67.7^{\dagger}$ & $0.21 \mathrm{NS}$ \\
\hline$P$ value between position groups & $0.26 \mathrm{NS}$ & $0.014 \mathrm{~S}$ & $0.013 \mathrm{~S}$ & -- \\
\hline Group $1 \mathrm{AaDpO}_{2}$ & $223+136.1$ & $137+61.8^{*}$ & $83+88.3^{*}$ & $0.03 \mathrm{~S}$ \\
\hline Group $2 \mathrm{AaDpO}_{2}^{2}$ & $232+171$ & $172+88.7$ & $137+122.7$ & $0.12 \mathrm{NS}$ \\
\hline Group $3 \mathrm{AaDpO}_{2}^{2}$ & $220+151$ & $209+83.1^{\dagger}$ & $151+101.4$ & $0.09 \mathrm{NS}$ \\
\hline$P$ value between position groups & $0.99 \mathrm{NS}$ & $0.026 \mathrm{~S}$ & $0.14 \mathrm{NS}$ & -- \\
\hline
\end{tabular}

Group 1-better lung down lateral position; Group 2-supine position; Group 3-better lung up lateral position. S- statistically significant; NS-statistically insignificant. “'”- $(P<0.05)$ significant changes for three groups of patient positioning; '†'- $(P<0.05)$ significant change from better lung down (group 1) position and supine position (group 2). 
Table 4: Distribution of bedsore grades on each side of pressure points in relation to lung score [number of patients (\%)]

\begin{tabular}{lccc}
\hline Grades of Bed Sore & Right-sided Bed Sore $(n=16)$ & Midline Bed Sore $(n=16)$ & Left-sided Bed Sore $(n=16)$ \\
\hline 0 No changes & $10(62)$ & $8(50)$ & $6(38)$ \\
1 & $3(19)$ & $2(12)$ & $2(12)$ \\
2 & $3(19)$ & $2(12)$ & $7(44)$ \\
3 & 0 & $1(06)$ & $1(06)$ \\
4 & 0 & $3(20)$ & $1(06)$ \\
\hline
\end{tabular}

${ }^{\star} P<0.05$, statistically significant; high grades of skin pressure sore (3 and 4) were observed in midline pressure points, while low grades $(1,2)$ were common on left side in patients with worse left lung.

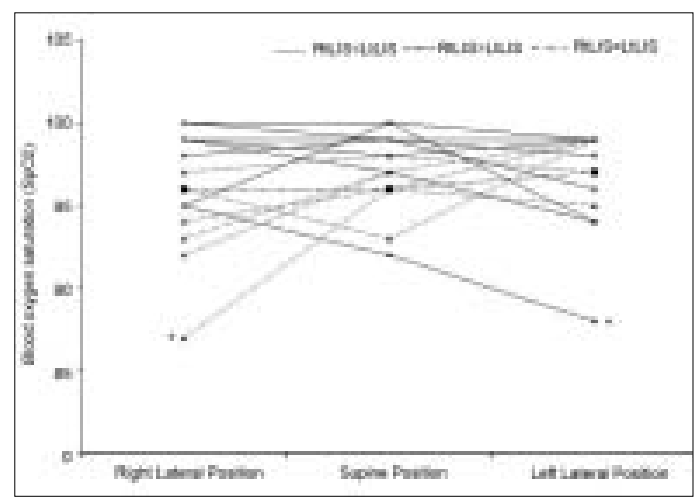

Figure 4: Blood arterial oxygen saturation $\left(\mathrm{SaO}_{2}\right)$ changes in all patients as observed in right lateral, supine and left lateral positions. Very small degrees of change in $\mathrm{SaO}_{2}$ are seen in spite of varied lung infiltration scores (LISs). Only 2 patients had significant (“*', $P<0.05$ ) fall in $\mathrm{SpO}_{2}$

poor due to its low compliance but there is preferential perfusion under gravity. ${ }^{[18,20,21]}$ Thus the ventilation-perfusion mismatch adds to right-to-left shunt and reduced oxygenation in patients with unilateral lung disease. ${ }^{[22,23]}$

In ARDS patients, diffuse and bilateral infiltrates in chest $x$-ray still represent a patchy lung atelectasis due to varied grades of the lung's disease. ${ }^{[17]}$ The mechanical ventilation with PEEP is frequently used to correct hypoxemia and improve lung function. ${ }^{\left[{ }^{8]}\right.}$ However, the aeration of alveoli by PEEP may not be uniform in different lung segments, being subject to severity of lung damage during insult. This process of patchy lung aeration in due course of therapy will predispose ARDS patients to postural hypoxemia.

While studies ${ }^{[10-12]}$ investigating the effects of lateral position in patients with bilateral lung infiltrates reported insignificant changes in oxygenation, $\mathrm{PaO}_{2}$ values in supine position were not always between those in the two lateral positions. ${ }^{[4]}$ Although asymmetry of the two-lung disease is not clear in these studies, we too did not find significant changes in oxygenation in patients of bilateral lung infiltrates till the LIS difference in the two lungs reached $\geq 3$. It was noteworthy that the pulse oximetry did not change significantly, probably due to upper ceiling of $100 \%$ saturation, but $\mathrm{PaO}_{2}$ improved significantly during better lungdown position. Since in this proposed LIS we took note of all the lung segments to map the differential lung changes, we could find $\mathrm{PaO}_{2}$, $\mathrm{PaO}_{2} / \mathrm{FiO}_{2}$ and $\mathrm{AaDpO}_{2}$ values for supine position to be in between those for the two lateral positions of the patients. Thus we could precisely map the differential lung involvement in bilateral lung disease and measure postural hypoxemia.

Gillespie et al. ${ }^{[7]}$ reported that in unilateral interstitial pulmonary disease, quantization of the ventilation-perfusion distribution did not show consistent differences between the 
patients in gas exchange. So besides improved ventilation-perfusion matching and decrease in right-to-left shunt, ${ }^{[7]}$ other factors like PEEP diverting pulmonary blood away from 'normal lung' to affected lung zones, ${ }^{[24]}$ hypoxemic vasoconstriction, ${ }^{[22]}$ vessel obliteration and extrinsic vessel compression ${ }^{[25]}$ contributed to affect oxygenation. Thus we presume that all these factors together contributed to the postural hypoxemia observed in our patients.

Peripheral oxygen delivery and peripheral tissue oxygenation are difficult to measure, and inadequate oxygen delivery to tissues results in the accumulation of glycolytic end products of metabolism with lactic acidosis, ${ }^{[26]}$ predisposing to pressure sores of skin. We too found significant postural hypoxemia (lowered $\mathrm{PaO}_{2}$ and $\mathrm{PaO}_{2} / \mathrm{FiO}_{2}$ ) with the patient lying on the worse-lung side. Although the small number of patients in this study imposes limits on the results, we feel that the postural hypoxemia probably predisposed patients to higher incidence of skin pressure sores on the weight-bearing bony points on the worse-lung (higher LIS) side.

Another limitation of this scoring system could be in allocating LIS in the presence of pleural effusion, which will match to the proposed LIS value of 2. Pleural effusion was not found in any of our patients; however, the differentiation between effusion and infiltration is possible by looking at mediastinal shift. Since pleural effusion too is reported to cast similar effect on oxygenation in lateral position, ${ }^{[27]}$ the LIS may still hold true to predict postural hypoxemia; however, this needs confirmation.

The nurses need to be aware of how different patient positions can affect arterial blood oxygenation within the critical care environment. ${ }^{[28]}$ Thus a basic acumen in nurses to adjudge the hazardous position of the ventilated patient shall help them to take care of, and protect, the patients in view of this fact. This simple LIS system of bedside chest $\mathrm{x}$-ray was useful in predicting asymmetry of lung ventilation in ARDS patients during mechanical ventilation. A large study based on LIS points given by the nurses to predict early-onset pressure sore needs to be undertaken in future.

\section{CONCLUSION}

Bilateral lung involvement of ARDS becomes patchy with the use of PEEP during mechanical ventilation. The proposed simple lung infiltration score predicted hypoxemia while lying on the worse lung in patients with LIS difference $\geq 3$ in chest $\mathrm{x}$-ray. The more frequent incidence of skin pressure sores on the worse-lung (higher LIS) side compared to the better-lung (lower LIS) side also correlated with hypoxemia noted in the same lateral position. Pulse oximetry may fail to give alarming signals. Thus postural hypoxemia can remain an unnoticed yet significant factor to induce early-onset skin pressure sore in critically ill patients.

\section{ACKNOWLEDGMENT}

The authors wish to thank Prof. C. M. Pandey for his valuable guidance in statistical analysis and interpretation. We also wish to thank Dr. Sue Smith for her help in editing in terms of language and giving a facelift to the manuscript.

\section{REFERENCES}

1. Fan E, Needham DM, Stewart TE. Ventilator 
management of acute lung injury and acute respiratory distress syndrome. JAMA 2005;94:2889-96.

2. Mennick F. Kinetic therapy: In search of the evidence. Am J Nurs 2004;104:2-22.

3. Schallom L, Metheny N, Stewart J, Schnelker R, Ludwig J, Sherman G. Short communication: Effect of frequency of manual turning on pneumonia. Am J Crit Care 2005;14:476-8.

4. Ibanez J, Raurich JM, Abizanda R, Claramonte R, Ibanez $\mathrm{P}$, Bergada J. The effect of lateral positions on gas exchange in patients with unilateral lung disease during mechanical ventilation. Intensive Care Med 1981;7:231-4.

5. King N. Positioning the ventilation patient with unilateral lung disease: A reflective account. Nurs Crit Care 1998;3:138-40.

6. Bons J, Dhainaut JF, Lesgourgues B, Schlemmer B, Carli A, Monsallier JF. Management of unilateral or asymmetrical lung disease. Anesth Analg (Paris) 1981;38:533-6.

7. Gillespie DJ, Rehder K. Body position and ventilation-perfusion relationship in unilateral pulmonary disease. Chest 1987;91:75-9.

8. Ashbaugh DG, Bigelow DB, Petty TL, Levine $\mathrm{BE}$. Acute respiratory distress in adults. Lancet 1967;2:319-23.

9. Pepe PE, Hudson LD, Carrico CJ. Early application of positive end-expiratory pressure in patients at risk for the adult respiratory-distress syndrome. N Engl J Med 1984;311:281-6.

10. Thomas PJ, Paratz JD, Lipman J, Stanton WR, PhD. Lateral positioning of ventilated intensive care patients: A study of oxygenation, respiratory mechanics, hemodynamics, and adverse events. Heart Lung 2007;36:277-86.

11. Kim $M$, Hwang $H$, Song $H$. A randomized trial on the effects of body positions on lung function with acute respiratory failure patients. Int J Nurs Stud 2002;39:549-55.

12. Banasik JL, Emerson RJ. Effect of lateral positions on tissue oxygenation in the critically ill. Heart Lung 2001;30:269-76.
13. Nelson LD, Anderson HB. Physiologic effects of steep positioning in the surgical intensive care unit. Arch Surg 1989;124:352-5.

14. Hunt J. Application of a pressure area risk calculator in an intensive care unit. Intensive Crit Care Nurs 1993;9:226-31.

15. Allman RN, Goode PS, Burst N, Bartolucci AA, Thomas DR. Pressure ulcers, hospital complications, and disease severity: Impact on hospital costs and length of stay. Adv Wound Care 1999;12:22-30.

16. Fife C, Otto G, Capsuto EG, Brandt K, Lyssy K, Murphy $\mathrm{K}$, et al. Incidence of pressure ulcers in a neurologic intensive care unit. Crit Care Med 2001;29:283-90.

17. Calandrino FS Jr, Anderson DJ, Mintun MA, Schuster DP. Pulmonary vascular permeability during the adult respiratory distress syndrome: A positron emission tomographic study. Am Rev Respir Dis 1988;138:421-8.

18. West JB, Dollery CT, Naimark A. Distribution of blood flow in isolated lungs: Relation to vascular and alveolar pressures. J Appl Physiol 1964;19:713-24.

19. Prokocimer P, Garbino J, Wolff M, Regnier B. Influence of posture on gas exchange in artificially ventilated patients with focal lung disease. Intensive Care Med 1983;9:69-72.

20. Rehder K, Hatch DJ, Sessler AD, Fowler WS. The function of each lung of anesthetized and paralyzed man during mechanical ventilation. Anesthesiology 1972;37:16-26.

21. Tokics L, Hedenstierna G, Svensson L, Brismar B, Cederlund $\mathrm{T}$, Lundquist $\mathrm{H}$, et al. V/Q distribution and correlation to atelectasis in anesthetized paralysed humans. J Appl Physiol 1996;81:182233.

22. Kaneko K, Milic-Emili J, Dolovich MB, Dawson A, Bates DV. Regional distribution of ventilation and perfusion as function of body position. J Appl Physiol 1966;21:767-77.

23. Arborelius M Jr, Lundin G, Svanberg L, Defares JG. Influence of unilateral hypoxia on blood flow 
through the lungs in the lateral position. J Appl Physiol 1960;15:595-7.

24. Kanarek DJ, Shannon DC. Adverse effect of positive end-expiratory pressure on pulmonary perfusion and arterial oxygenation. Am Rev Respir Dis 1975;112:457-9.

25. Vesconi S, Rossi GP, Pesenti A, Fumagalli R, Gattinoni L. Pulmonary microthrombosis in severe adult respiratory distress syndrome. Crit Care Med 1988;16:111-3.

26. Astiz ME, Rackow EC, Weil MH. Pathophysiology and treatment of circulatory shock. Crit Care Clin
1993;9:183-203.

27. Marklew A. Body positioning and its effect on oxygenation: A literature review. Nurs Crit Care 2006;11:16-22.

28. Duan LF, Lu SY, Ling AZ. Effect of position change on the $\mathrm{PaO} 2$ in patients with unilateral tuberculous pleural effusion. Zhonghua $\mathrm{Hu} \mathrm{Li} \mathrm{Za}$ Zhi 1997;32:190-1.

Source of Support: Nil. Conflict of Interest: None declared.

\section{Author Help: Reference checking facility}

The manuscript system (www.journalonw eb.com) allows the authors to check and verify the accuracy and style of references. The tool checks the references with PubM ed as per a predefined style. Authors are encouraged to use this facility, before submitting articles to the journal.

- The style as well as bibliographic elements should be $100 \%$ accurate, to help get the references verified from the system. Even a single spelling error or addition of issue number/month of publication will lead to an error when verifying the reference.

- $\quad$ Example of a correct style

Sheahan P, O'leary G, Lee G, Fitzgibbon J . Cystic cervical metastases: Incidence and diagnosis using fine needle aspiration biopsy. Otolaryngol Head Neck Surg 2002;127:294-8.

- $\quad$ Only the references from journals indexed in PubM ed will be checked.

- $\quad$ Enter each reference in new line, without a serial number.

- Add up to a maximum of 15 references at a time.

- If the reference is correct for its bibliographic elements and punctuations, it will be shown as CORRECT and a link to the correct article in PubM ed will be given.

- If any of the bibliographic elements are missing, incorrect or extra (such as issue number), it will be shown as INCORRECT and link to possible articles in PubM ed will be given. 